\title{
Hubungan Status GizidanPerkembangan Anak Usia 1-3 Tahun di Kelurahan Campurejo, Kecamatan Mojoroto, Kota Kediri
}

\author{
Susiani Endarwati, Siti Komariyah \\ Akademi Kebidanan Dharma Husada Kediri \\ susianiendarwati1@gmail.com, stijkr_kdr@yahoo.com
}

\begin{abstract}
Optimal development requires a balanced nutritional intake, especially in children aged 1-3 years (toddler). The role of parents is very important, ranging from providing nutrition, to help toddler achieve mental development and optimal cognition. Less nutrient intake, can result in abnormal toddler nutritional status (less nutrition). As a result, toddler will have problems on the development of toddler. The purpose of this study to determine the relationship of nutritional status and the development of children aged 1-3 years in the village Campurejo, district Mojoroto Kediri. The design of this research is analytical corellation with Cross Sectional research approach. The population of this research is children aged 1-3 years in Campurejo Village Kecamatan Mojoroto Kediri with Simple Random Sampling technique in get sample 52 respondents. The research variables consist of independent variable is Nutritional status of children aged 1 - 3 years and dependent variable is the development of children aged 1-3 years. The research instrument is in the form of Health Toward Card (KMS) and Denver Development Screening Test (DDST). Data were analyzed by Spearman correlation test, data analysis using SPSS v.20 program. Based on the result of research, nutritional status of 52 respondents studied got 23 respondents (44.23\%) good nutrition status and 2 respondents $(3.85 \%)$ malnutrition status. The result of the research is 52 respondents $(73.07 \%)$ normal development and 2 respondents (3.84\%) development of delay, the result of statistical test with Spermean Test obtained the result of $Z$ value 0,590 with $\alpha \leq 0,05$. H1 accepted means there is a relationship of nutritional status with the development of children aged 1-3 years.
\end{abstract}

Keywords: Nutrition Status, Development, Children aged 1-3 years.

\section{PENDAHULUAN}

Pembangunan nasional dewasa ini lebih dititikberatkan pada pembangunan ekonomi dan kualitas sumber daya manusia seutuhnya. Pemanfaatan sumber daya manusia dan sumber daya alam secara optimal mensyaratkan derajat status gizi dan kesehatan yang optimal. Menurut World Health Organization (WHO) menyatakan bahwa gizi adalah pilar utama dari kesehatan dan kesejahteraan sepanjang siklus kehidupan. Kejadian gizi buruk yang masih saja ada di Indonesia sampai saat ini akan berpengaruh langsung terhadap pertumbuhan dan perkembangan anak. Status gizi yang rendah berdampak pada penurunan kemampuan kognitif anak sehingga perkembangan anak mengalami keterlambatan (Soekirman, $2000: 6$ )

Gizi merupakan salah satu penentu kualitas sumber daya manusia yang jika kekurangan akan menyebabkan efek yang sangat serius seperti kegagalan pertumbuhan fisik serta tidak optimalnya perkembangan dan kecerdasan. Akibat lain adalah terjadinya penurunan produktifitas, menurunnya daya tahan tubuh terhadap penyakit yang akan meningkatkan resiko kesakitan dan kematian (Ariani, 2017:214)

Perkembangan yang optimal memerlukan asupan gizi yang seimbang terutama pada anak usia 1-3 tahun (toddler). Peran orang tua sangat penting, mulai dari pemberian nutrisi, hingga 
membantu toddler mencapai perkembangan mental dan daya kognisi yang optimal. Asupan gizi yang kurang, dapat mengakibatkan status gizi toddler tidak normal (gizi kurang). Akibatnya, toddler akan mengalami masalah pada perkembangan toddler.

Masalah gizi bisa berupa gizi lebih (Obesitas) atau gizi kurang (kurang kalori protein). Gizi kurang disebabkan oleh faktor langsung dan tidak langsung. Faktor penyebab tidak langsung meliputi tidak tersedianya pangan dalam rumah tangga, pola asuh anak yang tidak memadai, rendahnya tingkat pendidikan, pengetahuan dan ketrampilan orang tua, sedangkan faktor penyebab langsung meliputi asupan makanan yang tidak seimbang dan penyakit infeksi.

Dampak kurang gizi terhadap perkembangan mental dan otak tergantung dengan derajat beratnya, lamanya dan waktu pertumbuhan otak itu sendiri. Jika kondisi kurang Gizi terjadi pada Todler, khususnya pada golden periode perkembangan otak, otak tidak dapat berkembang sebagaimana anak yang sehat, dan kondisi ini akan sulit untuk dapat pulih kembali. Dengan demikian dikhawatirkan anak yang menderita gizi kurang pada usia toddler akan mengalami gangguan perkembangan yang bersifat menetap di masa - masa berikutnya(Nency\& Arifin, 2005).

\section{METODE PENELITIAN}

Desain penelitian ini adalah Analitik corellation dengan pendekatan penelitian Cross Sectional Populasi penelitian ini adalah Anak usia 1-3 tahun di Kelurahan Campurejo Kecamatan Mojoroto Kota Kediri dengan teknik Simple Random Sampling di dapatkan sampel 52 responden. Variabel penelitian terdiri dari variabel bebas adalah Status Gizi anak usia $1-3$ tahun dan variabel terikat adalah perkembangan anak usia 1-3 tahun.

Instrumen penelitian berupa buku Kartu Menuju Sehat (KMS) dan Denver Development Screening Test ( DDST ).
Data dianalisis dengan uji korelasi Spearman, analisis data menggunakan program SPSS v.20.

\section{HASIL DAN PEMBAHASAN Hasil}

Tabel III.1 Distribusi Frekuensi Status Gizi Anak usia 1-3 tahun di Kelurahan Campurejo , Kecamatan Mojoroto Kota Kediri

\begin{tabular}{|ll|r|r|r|r|}
\multicolumn{7}{|c|}{ Status_Gizi } \\
\hline & & Frequency & Percent & Valid Percent & $\begin{array}{c}\text { Cumulative } \\
\text { Percent }\end{array}$ \\
\hline Valid & Buruk & 2 & 3.8 & 3.8 & 3.8 \\
& Kurus & 21 & 40.4 & 40.4 & 44.2 \\
& Baik & 23 & 44.2 & 44.2 & 88.5 \\
& Lebih & 6 & 11.5 & 11.5 & 100.0 \\
& Total & 52 & 100.0 & 100.0 & \\
\hline
\end{tabular}

Berdasarkan Tabel III.1 dari 52 responden yang diteliti didapatkan 23 responden $(44,23 \%)$ status gizi baik dan 2 responden $(3,85 \%)$ status gizi buruk.

Tabel III.2 Distribusi Frekuensi Perkembangan Anak usia 1-3 tahun di Kelurahan Campurejo , Kecamatan Mojoroto Kota Kediri

\begin{tabular}{|c|c|c|c|c|c|}
\hline \multicolumn{6}{|c|}{ Perkembangan } \\
\hline & & Frequency & Percent & Valid Percent & $\begin{array}{l}\text { Cumulative } \\
\text { Percent }\end{array}$ \\
\hline \multirow[t]{5}{*}{ Valid } & Delay & 2 & 3.8 & 3.8 & 3.8 \\
\hline & Caution & 3 & 5.8 & 5.8 & 9.6 \\
\hline & Normal & 38 & 73.1 & 73.1 & 82.7 \\
\hline & Lebih & 9 & 17.3 & 17.3 & 100.0 \\
\hline & Total & 52 & 100.0 & 100.0 & \\
\hline
\end{tabular}

Berdasarkan Tabel III.2 dari 52 responden yang diteliti didapatkan 38 responden $(73,07 \%)$ perkembangan normal dan2 responden $(3,84 \%)$ perkembangan delay.

Tabel III.3 Tabulasi Silang Analisa Hubungan Status GizidanPerkembangan Anak Usia 1-3 Tahun di Kelurahan Campurejo , Kecamatan Mojoroto, Kota Kediri 


\begin{tabular}{|c|c|c|c|c|c|c|c|}
\hline \multicolumn{8}{|c|}{ Status_Gizi * Perkembangan Crosstabulation } \\
\hline & & & \multicolumn{4}{|c|}{ Perkembangan } & \multirow[b]{2}{*}{ Total } \\
\hline & & & Delay & Caution & Normal & Lebih & \\
\hline \multirow[t]{8}{*}{ Status_Gizi } & Buruk & Count & 1 & 1 & 0 & 0 & 2 \\
\hline & & $\%$ within Status_Gizi & $50.0 \%$ & $50.0 \%$ & $.0 \%$ & $.0 \%$ & $100.0 \%$ \\
\hline & Kurus & Count & 0 & 2 & 19 & 0 & 21 \\
\hline & & $\%$ within Status_Gizi & $.0 \%$ & $9.5 \%$ & $90.5 \%$ & $.0 \%$ & $100.0 \%$ \\
\hline & Baik & Count & 1 & 0 & 18 & 4 & 23 \\
\hline & & $\%$ within Status_Gizi & $4.3 \%$ & $.0 \%$ & $78.3 \%$ & $17.4 \%$ & $100.0 \%$ \\
\hline & Lebih & Count & 0 & 0 & 1 & 5 & 6 \\
\hline & & $\%$ within Status_Gizi & $.0 \%$ & $.0 \%$ & $16.7 \%$ & $83.3 \%$ & $100.0 \%$ \\
\hline \multirow[t]{2}{*}{ Total } & & Count & 2 & 3 & 38 & 9 & 52 \\
\hline & & $\%$ within Status_Gizi & $3.8 \%$ & $5.8 \%$ & $73.1 \%$ & $17.3 \%$ & $100.0 \%$ \\
\hline
\end{tabular}

Berdasarkan Tabel III.3 dari 52 responden yang diteliti didapatkan hasil :
a. Status Gizi buruk dengan perkembangan delay sebanyak 1 ( $1,92 \%$ ) anak
b. Status Gizi buruk dengan perkembangan caution sebanyak 1 ( $1,92 \%$ ) anak
c. Status Gizi kurus dengan perkembangan caution sebanyak 2 $(4,00 \%)$ anak

d. Status Gizi kurus dengan perkembangan normal sebanyak 19 ( $36,53 \%$ ) anak

e. Status Gizi baik dengan perkembangan delay sebanyak 1 ( $1,92 \%$ ) anak

f. Status Gizi baik dengan perkembangan normal sebanyak 18 $(34,61 \%)$ anak

g. Status Gizi baik dengan perkembangan lebih sebanyak 4 ( $7,69 \%$ ) anak

h. Status Gizi lebih dengan perkembangan normal sebanyak 1 $(1,92 \%)$ anak

i. Status Gizi lebih dengan perkembangan lebih sebanyak 5 ( $9,61 \%$ ) anak
Tabel III.4 Uji Statistik Pengaruh Dinamika Kelompok Sosial terhadap Status Gizi Anak Usia 1-3 tahun

Correlations

\begin{tabular}{|lll|r|r|}
\hline & & Status_Gizi & $\begin{array}{c}\text { Perkemb } \\
\text { angan }\end{array}$ \\
\hline Spearman's rho & Status_Gizi & Correlation Coefficient & 1.000 & $.590^{* *}$ \\
& & Sig. (2-tailed) &. & .000 \\
& & $\mathrm{~N}$ & 52 & 52 \\
\cline { 2 - 5 } & & $.590^{* *}$ & 1.000 \\
& & .000 &. \\
& & 52 & 52 \\
\hline
\end{tabular}

Berdasarkan Tabel III.4 Hasil uji statistik dengan Spermean Test diperoleh hasil nilai $\mathrm{Z}$ sebesar 0,590 dengan $\alpha \leq$ 0,05 . H1 diterima artinya ada hubungan status gizi dengan perkembangan anak usia 1-3 tahun.

\section{PEMBAHASAN}

\section{Status Gizi Anak Usia 1-3 tahun di Kelurahan Campurejo Kecamatan Mojoroto Kota Kediri}

Berdasarkan Tabel III.1 dari 52 responden yang diteliti didapatkan 23 responden $(44,23 \%)$ status gizi baik, 21 responden $(40,38 \%), 6$ responden $(11,53 \%)$ dan 2 responden $(3,85 \%)$ status gizi buruk.

Status gizi yang baik sangat diperlukan untuk proses tumbuh kembang anak anak yang normal ditinjau dari segi umur. Kekurangan gizi pada balita jika dibiarkan secara terus menerus secara tidak langsung akan memberikan dampak terhadap penurunan kualitassumber daya manusia. (Shirin S, 2016)

Hasil penelitian menunjukkan sebagian besar responden memiliki status gizi yang baik. Pengetahuan ibu tentang kebutuhan gizi memegang peranan yang sangat penting, hal ini terjadi karena kebutuhan akan zat gizi dapat menciptakan generasi mendatang yang lebih baik. Akan tetapi kesadaran akan pentingnya pemberian gizi yang baik kadang belum sepenuhnya dimengerti.

Berdasarkan tabel III.1 didapatkan 2 responden $(3,85 \%)$ status gizinya buruk. 
Beberapa faktor yang sering terjadi dimana merupakan penyebab terjadinya gangguan gizi baik langsung maupun tidak langsung. Sebagai penyebab langsung gangguan gizi khususnya gangguan gizi pada bayi dan balita adalah tidak sesuai jumlah gizi yang mereka peroleh dari makanan dengan kebutuhan tubuh mereka.

Kesukaan yang berlebihan terhadap jenis makanan tertentu atau disebut sebagai fatddisme makanan akan mengakibatkan tubuh tidak memperoleh semua zat gizi yang diperlukan. (Hasdianah, Siyoto, 2014 :104)

Anak usia 1-3 tahun kebanyakan mereka memiliki kesukaan terhadap jenis makanan tertentu, hal ini yang mengakibatkan pola konsumsi makanan anak hanya seputar makanan jenis tertentu yang pada akhirnya memaksa ibu untuk memberikan makanan tersebut lebih sering. Dampak yang dapat terjadi adalah anak akan mengalami kekurangan pada zat gizi tertentu karena makanan yang di konsumsi kurang bervariasi.

\section{Perkembangan Anak Usia 1-3 tahun di Kelurahan Campurejo Kecamatan Mojoroto Kota Kediri}

Berdasarkan Tabel III.2 dari 52 responden yang diteliti didapatkan 38 responden $(73,07 \%)$ perkembangan normal, 3respoden $(5,07 \%)$ perkembangan Caution, 9responden $(17,40 \%)$ perkembangan lebih dan 2 responden $(3,84 \%)$ perkembangan delay

Data ini menunjukkanbahwa sebagian besar responden telah menunjukkan fase perkembangan yang normal atau sesuai dengan usianya. Namun, masih adanya anak usia toddler yang perkembangannya mengalami penyimpangan. Hasil penelitian ini dipengaruhi oleh faktor pengetahuan ibu, hal ini dikarenakan, ketidak tahuan orang tua tentangtahap-tahap perkembangan anak sesuai umur dan juga stimulasi yang diberikan. Sehingga, anak hanya diajarkan oleh orang tua tersebut sebatas pengetahuannya. Responden yang orang tuanya yang mempunyai pengetauan baik tidak ada yang mengalami penyimpangan tahap perkembangan. Hal ini dikarenakan, orang tua anak tersebut paham dan tahu tentang perkembangan anak berdasarkan umur. Hasil ini menunjukkan bahwa semakin tinggi pendidikan atau pengetahuan seseorang maka perkembangan anaknya juga akan semakin baik. Hasil penelitian ini sesuai dengan pendapat yang menyatakan bahwa dengan pendidikan yang baik, maka orang tua akan dapat menerima segala informasi dari luar terutama tentang cara pengasuhan anak yang baik, bagaimana menjaga kesehatan anaknya, pendidikannya dan sebagainya (Hanum, 2008).

\section{Hubungan Status}

GizidanPerkembangan Anak Usia 13 Tahun di Kelurahan Campurejo, Kecamatan Mojoroto, Kota Kediri

Hasil uji statistik menunjukkan Spermean Test diperoleh hasil nilai $\mathrm{Z}$ sebesar 0,338 dengan $\alpha \leq 0,05$. sehingga $\mathrm{H} 0$ ditolak dan $\mathrm{H} 1$ diterima.Artinya adalah ada hubungan yang signifikanantara status gizi dengan perkembangan anakusia 1- 3 tahun.Hasil penelitian ini menunjukkan bahwafaktor gizi sangat berperan dalam menentukanperkembangan anak. Anak yang kurang gizicenderung mengalami gangguanperkembangan, sedangkan anak yang gizinyacukup atau baik maka perkembangannya akanberjalan sesuai usianya.Hasil penelitian ini sesuai dengan teoriyang menjelaskan bahwa nutrisi menjadikebutuhan untuk menunjang perkembangan.Dalam nutrisi terdapat kebutuhan zat gizi yangdiperlukan untuk perkembangan sepertiprotein, karbohidrat, lemak, mineral danvitamin dan air. Apabila kebutuhan nutrisiseseorang kurang terpenuhi, maka dapatmenghambat perkembangan (Hidayat, 2008).

Hal ini sesuai dengan pernyataan bahwa intake gizi yang baik berperan 
penting di dalam mencapai pertumbuhan badan yang optimal. Dan pertumbuhan badan yang optimal ini mencakup pula pertumbuhan otak yang sangat menentukan kecerdasan seseorang. Perkembangan anak menurut DDST yang terdiri dari motorik kasar, bahasa, motorik halus dan personal sosial diatur oleh areaarea tertentu dalam otak. Energi dan protein berpengaruh terhadap pertumbuhan dan perkembangan jaringan otak. Berbagai mikronutrien juga mempengaruhi perkembangan jaringan otak. Kekurangan seng $(\mathrm{Zn})$ dan besi $(\mathrm{Fe})$ misalnya, secara langsung menimbulkan gangguan pertumbuhan dan perkembangan otak. Selain itu disebutkan pula zat-zat tersebut ada relevansinya dengan perbanyakan sel glia, myelinasi, pertumbuhan dendrit dan pembentukan sinaps (Syakira,2009).

\section{KESIMPULAN}

Status gizi balita di kelurahan Lirboyo mayoritas adalah baik sebanyak $23(44,23 \%)$ anak. Perkembangan anak di kelurahan adalah mayoritas normal sebanyak 38 ( 73,07\% ) anak. Hasil analisi statistik dengan spermen test didapatkan nilai $\mathrm{Z}$ hitung sebesar 0,590 , yang artinya ada hubungan antara status gizi dengan perkembangan anak dengan

\section{SARAN}

Meskipun hasil mayoritas dari status gizi baik, namun masih ada anak yang mengalami status gizi buruk, maka dapat disarankan perlu adanya dinamika kelompok dibidang gizi maupun kesehatan, untuk meningkatkan status gizi anak. Hasil penelitian menunjukkan tingkat perkembangan mayoritas normal, namun ada masih ada anak yang mengalami delay meskipun jumlahnya sedikit, sehingga masih perlu dilakukan dinamika kelompok mengenai perkembangan anak mengingat banyak orangtua yang masih kurang paham mengenai perkembangan anak yang optimal serta stimulus yang seharusnya diberikan kepada anaknya. Penyuluhan ini dapat berupa permainan dan simulasi agar orangtua tidak merasa jenuh saat mendengarkan materi yang diberikan.

\section{DAFTAR PUSTAKA}

Ariani, Putri. 2017. Ilmu Gizi. Yogjakarta

: Nuha Medika

Hanum. (2008). Tumbuh Kembang, Status Gizi, dan Imunisasi Dasar Pada Balita. Yogyakarta. : Nuha Medika.

Hasdianah, Siyoto, Sandu H. Nurwijayanti. 2014. Gizi, Pemanfaatan Gizi, Diet, dan Obesitas. Yogjakarta : Nuha Medika.

Mariani Gabriela K. 2015. Hubungan status gizi dengan perkembangan motorik halus pada anak usia prasekolah di TK GMIM Solafide Kelurahan Uner Kecamatan Kawangkoan Induk. E journal keperawatan (e-kp) Vol 3 No 1 Februari 2015.

Mubarak, Wahit Iqbal. 2011. Promosi Kesehatan Untuk Kebidanan. Jakarta : Salemba Medika

Sobirin, Gilang. 2013. Hubungan Antara Status Gizi Dengan Perkembangan Toddler Di Kelurahan Telukan Kecamatan Grogol Kabupaten Sukoharjo.

Soetjiningsih. 2012. Tumbuh Kembang Anak. Jakarta : EGC

Wawan, A dan Dewi. 2010. Teori \& Pengukuran Pengetahuan, Sikap, dan Perilaku Manusia. Yogyakarta: Nuha Medika. 